\title{
Helicobacter pylori eradication with either seven-day or 10-day triple therapies, and with a 10-day sequential regimen
}

\author{
Giuseppe Scaccianoce $M D^{1}$, Cesare Hassan $M D^{2}$, Alba Panarese $M D^{1}$, Donato Piglionica $M D^{1}$, \\ Sergio Morini $\mathrm{MD}^{2}$, Angelo Zullo MD²
}

G Scaccianoce, C Hassan, A Panarese, D Piglionica, S Morini, A Zullo. Helicobacter pylori eradication with either seven-day or 10-day triple therapies, and with a 10-day sequential regimen. Can J Gastroenterol 2006;20(2):113-117.

BACKGROUND: Helicobacter pylori eradication rates achieved by standard seven-day triple therapies are decreasing in several countries, while a novel 10-day sequential regimen has achieved a very high success rate. A longer 10-day triple therapy, similar to the sequential regimen, was tested to see whether it could achieve a better infection cure rate.

METHODS: Patients with nonulcer dyspepsia and $H$ pylori infection were randomly assigned to one of the following three therapies: esomeprazole $20 \mathrm{mg}$, clarithromycin $500 \mathrm{mg}$ and amoxycillin $1 \mathrm{~g}$ for seven days or 10 days, or a 10-day sequential regimen including esomeprazole $20 \mathrm{mg}$ plus amoxycillin $1 \mathrm{~g}$ for five days and esomeprazole $20 \mathrm{mg}$, clarithromycin $500 \mathrm{mg}$ and tinidazole $500 \mathrm{mg}$ for the remaining five days. All drugs were given twice daily. H pylori eradication was checked four to six weeks after treatment by using a ${ }^{13} \mathrm{C}$-urea breath test.

RESULTS: Overall, 213 patients were enrolled. H pylori eradication was achieved in $75.7 \%$ and $77.9 \%$, in $81.7 \%$ and $84.1 \%$, and in $94.4 \%$ and $97.1 \%$ of patients following seven-day or 10 -day triple therapy and the 10-day sequential regimen, at intention-to-treat and per protocol analyses, respectively. The eradication rate following the sequential regimen was higher than either seven-day $(\mathrm{P}=0.002)$ or 10 -day triple therapy $(\mathrm{P}=0.02)$, while no significant difference emerged between the latter two regimens $(\mathrm{P}=0.6)$.

CONCLUSIONS: The 10-day sequential regimen was significantly more effective than both triple regimens, while 10-day triple therapy failed to significantly increase the $H$ pylori eradication rate achieved by the standard seven-day regimen.

Key Words: Bacterial load; Helicobacter pylori; Sequential therapy; Triple therapy

H elicobacter pylori plays a crucial role in the pathogenesis of chronic active gastritis, peptic ulcer and mucosa-associated lymphoid tissue lymphoma, and its involvement in gastric carcinogenesis is also of mounting concern (1-4). Although the association between $H$ pylori and nonulcer dyspepsia is still debatable, two comprehensive systematic reviews showed a small but significant benefit to curing this infection $(5,6)$. $\mathrm{H}$ pylori causes significant morbidity and mortality with a relevant

\section{La suppression d'Helicobacter pylori : la trithérapie de 7 jours ou de 10 jours par rap- port à la thérapie séquentielle de 10 jours}

\begin{abstract}
CONTEXTE : Le taux de suppression d'Helicobacter pylori obtenu par la trithérapie courante de 7 jours est en voie de diminution dans plusieurs pays, mais une nouvelle thérapie séquentielle de 10 jours atteint un très bon taux de réussite. Nous avons donc vérifié si la trithérapie prolongée à 10 jours, selon le modèle de la thérapie séquentielle, pouvait améliorer le taux de guérison de l'infection.

MÉTHODE : Des patients souffrant de dyspepsie non ulcéreuse et d'une infection à $H$. pylori ont été soumis au hasard à l'un des trois traitements suivants : ésoméprazole, $20 \mathrm{mg}$; clarithromycine, $500 \mathrm{mg}$ et amoxycilline, $1 \mathrm{~g}$, durant 7 jours ou durant 10 jours, en trithérapie; ou encore ésoméprazole, $20 \mathrm{mg}$ et amoxycilline, $1 \mathrm{~g}$ durant 5 jours, puis ésoméprazole, $20 \mathrm{mg}$; clarithromycine, $500 \mathrm{mg}$ et tinidazole, $500 \mathrm{mg}$ durant les 5 derniers jours, en thérapie séquentielle de 10 jours. Les médicaments étaient tous à prise biquotidienne. La suppression d'H. pylori a été vérifiée de quatre à six semaines après le traitement à l'aide de l'épreuve respiratoire à l'urée marquée au carbone-13.
\end{abstract}

RÉSULTATS : Au total, 213 patients ont participé à l'étude. Il y a eu suppression d'H. pylori chez $75,7 \%$ et $77,9 \% ; 81,7 \%$ et $84,1 \% ; 94,4 \%$ et $97,1 \%$ des patients après la trithérapie de 7 jours ou de 10 jours ou encore après la thérapie séquentielle de 10 jours, selon l'analyse fondée sur le principe de vouloir traiter ou l'analyse fondée sur le protocole, respectivement. Le taux de suppression suivant la thérapie séquentielle a été plus élevé que celui atteint par la trithérapie de 7 jours $(\mathrm{P}=0,002)$ ou de 10 jours $(\mathrm{P}=0,02)$, et aucun écart significatif ne séparait les deux dernières modalités $(\mathrm{P}=0,6)$.

CONCLUSIONS : La thérapie séquentielle de 10 jours s'est montrée significativement supérieure à la trithérapie de 7 jours ou de 10 jours; de plus, la trithérapie de 10 jours n'a pas permis d'augmentation sensible du taux de suppression d'H. pylori par rapport à celui atteint par la thérapie courante de 7 jours.

economic impact, thus requiring an appropriate therapeutic approach. A triple therapy, comprising proton pump inhibitor, clarithromycin and amoxycillin or metronidazole, is among the most used first-line treatments in primary medical care in several countries including Canada, the United States and Europe (7-10). However, during the past few years, different studies have found that the success rate following such regimens is decreasing in several countries. Indeed, two large

${ }^{1}$ Digestive Endoscopy, "Umberto I" Hospital, Altamura, Bari; ${ }^{2}$ Gastroenterology and Digestive Endoscopy, "Nuovo Regina Margherita" Hospital, Roma, Italy

Correspondence: Dr Angelo Zullo, Ospedale Nuovo Regina Margherita, Gastroenterologia ed Endoscopia Digestiva, Via E Morosini, 30,00153

Rome, Italy. Telephone 0039-06-5844-6608, fax 0039-06-5844-6533, e-mail gastroroma@virgilio.it

Received for publication May 4, 2005. Accepted July 14, 2005 
meta-analyses $(11,12)$ showed that these therapies failed to eradicate $H$ pylori in up to $20 \%$ of patients. Moreover, even lower cure rates have been observed in primary medical care settings, with bacterial eradication being achieved in only $61 \%$ to $76 \%$ of patients (8). Some studies have evaluated the efficacy of triple therapies administered for 10 days or even 14 days, with controversial results. However, a recent meta-analysis (13) has clearly shown that the 10 -day regimen offers a disappointing therapeutic gain of only $3 \%$ compared with that of seven-day triple therapy. A different combination of the antibiotics available, consisting of a novel 10-day sequential regimen, has been recently studied (14). This schedule is a simple dual therapy (proton pump inhibitor plus amoxycillin) given for the first five days followed by a triple therapy (proton pump inhibitor, clarithromycin and tinidazole) for the remaining five days. This sequential regimen was proven to be highly successful in a very large, multicentre study compared with the standard seven-day triple therapy (92\% versus $74 \%$, respectively; intention-to-treat [ITT] analysis) (15).

It has been found that $H$ pylori bacterial density in gastric mucosa is a factor involved in the antibiotic therapy outcome. Indeed, some studies have found that a high bacterial load is associated with a low eradication rate following both standard seven-day triple therapy and 14-day course of bismuth salts, tetracycline and metronidazole $(16,17)$. To our knowledge, no data are available about the role of bacterial density on the efficacy of both 10-day triple therapy and a 10-day sequential regimen. The present study aimed to compare the efficacy of the 10 -day sequential regimen with that of 10-day triple therapy; to further test whether the longer 10-day triple therapy was able to increase the eradication rate compared with the standard seven-day regimen; and to evaluate the role of bacterial load on therapeutic outcome.

\section{PATIENTS AND METHODS}

\section{Patients}

This was a prospective, parallel, open-label, two-centre, randomized study. The study population consisted of patients with dyspepsia - defined as pain or discomfort centred in the upper abdomen - who were referred by primary care physicians for upper endoscopy.

Consenting patients were enrolled if they were infected with $H$ pylori. Patients enrolled in the present study had not been enrolled in other studies and had not been previously treated for $H$ pylori infection. Patients were excluded if they were taking proton pump inhibitors, $\mathrm{H}_{2}$-receptor antagonists or antibiotics in the four weeks preceding the study. Pregnant women, patients with known antibiotic allergy, and those with hepatic impairment or kidney failure were not enrolled. All participants gave written informed consent.

\section{$H$ pylori assessment}

At entry, all patients underwent endoscopy with biopsies for histology (two samples from the antrum and two samples from the corpus) and a rapid urease test (one sample from the antrum) (CP-test, Italy). Patients were considered $\mathrm{H}$ pylori-positive if both tests were positive. Biopsy specimens were histologically assessed for the presence of $\mathrm{H}$ pylori (hematoxylin and eosin stain) and to assess bacterial density (Giemsa staining), as previously reported $(18,19)$. Briefly, the following semiquantitative grading was used: mild (focal presence of a small amount of bacteria); moderate (intermediate amount between mild and marked); and marked (diffuse presence of a large amount of bacteria). For the purposes of the present study, patients with peptic ulcer at endoscopy, defined as a mucosal ulceration $5 \mathrm{~mm}$ or greater in diameter in the stomach or duodenum, as well as those with a documented history of peptic ulcer were not enrolled. Bacterial eradication was checked four to six weeks after treatment completion by using a ${ }^{13} \mathrm{C}$-urea breath test (Infai, Sofar, Italy). Citric acid ( $\left.1.5 \mathrm{~g}\right)$ as a test meal and ${ }^{13} \mathrm{C}$-urea $(75 \mathrm{mg})$ as a water solution was given to the patients after collection of a baseline sample, obtained by blowing through a disposable plastic straw into a $20 \mathrm{~mL}$ container; an additional breath sample was collected 30 min later. The breath samples were considered positive if there was a greater than five per 1000 of ${ }^{13} \mathrm{CO}_{2}$ difference over baseline, according to the manufacturer's recommendations.

\section{Therapy regimens}

In each centre, patients were randomly assigned using a computergenerated list to one of the following treatments:

1. A seven-day triple therapy comprising esomeprazole $20 \mathrm{mg}$, clarithromycin $500 \mathrm{mg}$ and amoxycillin $1 \mathrm{~g}$, all given twice daily;

2. A 10-day triple therapy comprising esomeprazole $20 \mathrm{mg}$, clarithromycin $500 \mathrm{mg}$ and amoxycillin $1 \mathrm{~g}$, all given twice daily; or

3. A 10-day sequential regimen comprising esomeprazole $20 \mathrm{mg}$ daily plus amoxycillin $1 \mathrm{~g}$ for the first five days, both given twice daily, followed by esomeprazole $20 \mathrm{mg}$, clarithromycin $500 \mathrm{mg}$ and tinidazole $500 \mathrm{mg}$ for the remaining five days, all given twice daily.

For each therapy regimen, the proton pump inhibitor was prescribed before breakfast and supper, whereas all antibiotics were given after these meals. Patients were asked to return at the end of the treatment to assess the compliance with therapy and to estimate the incidence of side effects. Compliance was defined as consumption of greater than $90 \%$ of the prescribed drugs and was determined by pill counts at the follow-up visit. Side effects were evaluated using a structured questionnaire by personal interview.

\section{Statistical analysis}

The sample size was a priori calculated based on available data in the literature. By hypothesizing a 95\% eradication rate for the sequential regimen (18) and $80 \%$ for either 10 -day or seven-day triple therapy (12), it was calculated that at least 68 patients per treatment arm were needed to find a statistically significant difference with a level of $\mathrm{P}<0.05$ and a power of 0.85 . The eradication rates and their 95\% CIs at both ITT and per protocol (PP) analyses were calculated for each treatment regimen. For all other variables, $\chi^{2}$, Fisher's exact test and Student's $t$ test were used as appropriate, and $\mathrm{P}<0.05$ was considered significant. The difference between the proportions eradicated using the three treatments was estimated for each centre. Before pooling those estimates, a Fisher's exact test was applied to investigate heterogeneity between the differences.

\section{Eradication rates}

\section{RESULTS}

Two hundred thirteen consecutive dyspeptic patients were enrolled in the study. As shown in Table 1, the three patient groups did not differ in age, sex, gastritis distribution and bacterial density in gastric mucosa. Overall, six patients (two patients 
TABLE 1

Demographic and clinical characteristics of patients at entry into each treatment group

\begin{tabular}{lccc}
\hline $\begin{array}{l}\text { Patient } \\
\text { characteristics } \\
\text { (n) }\end{array}$ & $\begin{array}{c}\text { Seven-day } \\
\text { triple } \\
\text { therapy }\end{array}$ & $\begin{array}{c}\text { 10-day } \\
\text { triple } \\
\text { therapy }\end{array}$ & $\begin{array}{c}\text { 10-day } \\
\text { sequential } \\
\text { therapy }\end{array}$ \\
\hline Number of patients & 70 & 71 & 72 \\
Sex (male/female) & $34 / 36$ & $33 / 38$ & $32 / 40$ \\
Age, mean \pm SD (years) & $54 \pm 12$ & $53 \pm 16$ & $55 \pm 14$ \\
Antral gastritis & 59 & 59 & 61 \\
Pangastritis & 11 & 12 & 11 \\
Intestinal metaplasia & 13 & 13 & 15 \\
Bacterial density & & & 25 \\
Low & 20 & 23 & 39 \\
Moderate & 44 & 40 & 8 \\
Marked & 6 & 8 & \\
\hline
\end{tabular}

in each treatment group) stopped the treatment within three days, and they did not undergo ${ }^{13} \mathrm{C}$-urea breath testing. Therefore, the final PP population consisted of 207 patients. $H$ pylori infection was cured in 53 patients treated with sevenday triple therapy, in 58 of those receiving 10-day triple therapy and in 68 treated with the 10-day sequential regimen. By ITT analysis, no significant difference emerged in eradication rates between the two participating centres for each treatment schedule. In detail, $H$ pylori infection was successfully cured in $77.9 \%$ and $75.7 \%$, in $84.1 \%$ and $81.7 \%$, and in $97.1 \%$ and $94.4 \%$ following seven-day triple therapy, 10 -day triple therapy and 10-day sequential regimen, at both ITT and PP analyses, respectively. As shown in Table 2, the eradication rates achieved by the sequential regimen were significantly higher than both seven-day and 10-day triple therapies, both at ITT and PP analyses. Although the 10-day regimen tended to give better results when compared with seven-day therapy, no statistically significant difference in the eradication rate was found. In the patient group treated with seven-day triple therapy, the $H$ pylori eradication rate was significantly lower in patients with a high (moderate or marked) bacterial density compared with those with a low (mild) bacterial load in the stomach $(70.8 \%$ versus $95 \%$; $\mathrm{P}=0.02$ ). Of interest, such a phenomenon was not similarly evident for 10-day triple therapy; the trend was not statistically significant $(80.9 \%$ versus $90.9 \% ; P=0.2)$. With the sequential regimen, the trend was also not significant $(95.6 \%$ versus $100 \% ; \mathrm{P}=0.4$ ).

\section{Compliance and side effects}

Compliance with the therapy was good (greater than $95 \%$ of prescribed drugs) in all but six patients, who had stopped the treatment early because of side effects. Seven patients (10\%) treated with seven-day triple therapy complained of side effects (two with diarrhea, two with abdominal pain, one with urticaria and one with glossitis), and two of them interrupted treatment. Nine patients $(12.7 \%)$ receiving 10 -day triple therapy reported side effects (two with abdominal pain, three with diarrhea, two with glossitis, nausea/vomiting in one and pruritus in one), and two of them stopped treatment. Eight patients $(11.1 \%)$ receiving the 10 -day sequential regimen complained of side effects (three with diarrhea, three with abdominal pain, one with glossitis and one with
TABLE 2

Eradication rates both at intention-to-treat (ITT) and per protocol (PP) analyses

\begin{tabular}{cccc}
\hline Analysis & $\begin{array}{c}\text { Seven-day } \\
\text { triple therapy }\end{array}$ & $\begin{array}{c}\text { 10-day } \\
\text { triple therapy }\end{array}$ & $\begin{array}{c}\text { 10-day } \\
\text { sequential therapy }\end{array}$ \\
\hline ITT $(\%)^{*}$ & $53 / 70(75.7)$ & $58 / 71(81.7)$ & $68 / 72(94.4)$ \\
$95 \% \mathrm{Cl}$ & 66 to 86 & 73 to 91 & 89 to 100 \\
$\mathrm{PP}(\%)^{\dagger}$ & $53 / 68(77.9)$ & $58 / 69(84.1)$ & $68 / 70(97.1)$ \\
$95 \% \mathrm{Cl}$ & 68 to 88 & 75 to 93 & 93 to 100
\end{tabular}

*Ten-day sequential versus seven-day triple therapy: $P=0.002$; 10-day sequential versus 10-day triple therapy: $P=0.02$; Seven-day triple versus 10-day triple therapy: $P=0.6$; $† 10$-day sequential versus seven-day triple therapy: $P=0.004$; 10 -day sequential versus 10-day triple therapy: $P=0.034$ Seven-day triple versus 10-day triple therapy: $P=0.6$

nausea/vomiting); two of the eight patients interrupted treatment. No statistically significant difference in the incidence of side effects emerged among the three treatment regimens. All side effects were self-limiting after therapy ended.

\section{DISCUSSION}

Triple therapies endorsed by either Canadian or European guidelines are currently the most preferred first-line therapy regimens in clinical practice worldwide $(2,20)$. For instance, these therapeutic approaches are used by $85 \%, 84 \%$ and $67 \%$ of primary-care physicians in Italy, Israel and the United States, respectively (8-10). However, the $H$ pylori eradication rates following triple therapy are decreasing substantially in several countries. Indeed, an unacceptable (less than 80\%) success rate has been consistently found in several European and Asian countries as well as in the United States and Canada (21-29), with an eradication rate as low as $25 \%$ reported in a recent study (30). Moreover, bacterial eradication following a failed initial standard triple therapy is notoriously difficult to achieve; this further questions the suitability of such a therapy regimen (31). An overall disappointing cure rate after seven-day triple therapy has been further confirmed in the present study, especially in those patients harbouring a high bacterial density. Therefore, continued searching for novel therapeutic approaches to cure $\mathrm{H}$ pylori is needed, the best first-line treatment being also regarded as the best 'rescue' therapy for such a frequent, worldwide infection (31). Unfortunately, the rational, simple attempt to increase the duration of triple therapy to beyond seven days has been disappointing, and the results of the present investigation are in agreement with those of other studies $(13,32)$. However, our data found that the efficacy of the prolonged triple therapy regimen did not seem to be affected by the bacterial load as much as seven-day therapy was, although neither the relatively small sample size nor the semiquantitative method used allows us to draw definitive conclusions.

Ideally, a first-line treatment for $\mathrm{H}$ pylori should be highly effective (greater than 90\% eradication rate), safe, short and inexpensive. To find such a treatment, new therapeutic combinations have been pioneered in the past five years. A seven-day quadruple regimen, including a proton pump inhibitor plus bismuth salts, tetracycline and metronidazole, has been used as a first-line regimen in some studies. However, a meta-analysis failed to find a significant difference in the success rate between seven-day quadruple and standard triple therapy (33). Recently, high eradication rates (greater than 90\%) were 
achieved following a 14-day quadruple regimen in a pilot study (34), but side effects were experienced by as many as $49 \%$ of patients, so that its use in primary clinical practice has been questioned (35). New levofloxacin-based triple therapies achieving high $\mathrm{H}$ pylori eradication rates have been also proposed (36). However, levofloxacin is quite expensive, so this regimen is presumably suitable as a retreatment option in patients with eradication failure $(37,38)$. High-dose lactoferrin supplementation to standard seven-day triple therapy has been found to significantly increase the infection cure rate in one pilot study (39) but not in another (40). Therefore, these data deserve to be confirmed in further studies.

The 10-day sequential regimen has been validated in a very large number of patients enrolled in several studies performed in Italy in the past few years $(14,15,41-44)$. In detail, the sequential regimen has been shown to be highly effective (93.5\% eradication rate in 1208 patients; $95 \%$ CI 92 to 95 ), safe, relatively short and cost-effective when compared with other strategies $(43,45)$. In addition, we found previously that this sequential regimen was significantly more effective than seven-day triple therapy even in patients harbouring either clarithromycin- (79\% versus $27 \%$, respectively) or metronidazole-resistant strains (91\% versus $67 \%$, respectively) (14). The importance of such a sequential regimen has also been recently recognized by others $(13,46)$.

The rationale of the sequential regimen is in the administration of an initial dual therapy with amoxycillin, which is able to eradicate $H$ pylori in some patients and to reduce the bacterial load in all the remaining cases, without inducing bacterial resistance (15). Of interest, regimens containing amoxycillin may prevent the selection of secondary clarithromycin resistance (47). Furthermore, reducing the bacterial load significantly improves the response to the immediately subsequent short course of triple therapy, as clearly shown in another study (16). In addition, the sequential regimen exploits the efficacy of three different antibiotics, instead of the two in the triple standard therapy.

It has been argued that the higher effectiveness of the sequential regimen compared with seven-day triple therapy could be related to its duration, rather than to the sequential administration of drugs (48). In the present study, we found that the 10-day sequential regimen achieved very high eradication rates that were distinctly higher even when compared

\section{REFERENCES}

1. Huang JQ, Hunt RH. The evolving epidemiology of Helicobacter pylori infection and gastric cancer. Can J Gastroenterol 2003;17 (Suppl B):18-20.

2. Malfertheiner P, Megraud F, O'Morain C, et al. Current concepts in the management of Helicobacter pylori infection - The Maastricht 2-2000 Consensus Report. Aliment Pharmacol Ther 2002;16:167-80.

3. Vaira U, Gatta L, Ricci C, D'Anna L, Iglioli MM. Helicobacter pylori: Diseases, tests and treatment. Dig Liver Dis 2001;33:788-94.

4. Nardone G. Risk factors for cancer development in Helicobacter pylori gastritis. Dig Liver Dis 2000;32(Suppl 3):190-2.

5. Moayyedi P, Deeks J, Talley NJ, Delaney B, Forman D. An update of the Cochrane systematic review of Helicobacter pylori eradication therapy in nonulcer dyspepsia: Resolving the discrepancy between systematic reviews. Am J Gastroenterol 2003;98:2621-6.

6. Abraham NS, Moayyedi P, Daniels B, Veldhuyzen Van Zanten SJ Systematic review: The methodological quality of trials affects estimates of treatment efficacy in functional (non-ulcer) dyspepsia. Aliment Pharmacol Ther 2004;19:631-41.

7. Hunt RH, Fallone CA, Thomson AB. Canadian Helicobacter pylori Consensus Conference update: Infections in adults. Canadian Helicobacter Study Group. Can J Gastroenterol 1999;13:213-7. with those of 10-day triple therapy. Therefore, it could be suggested that the higher successful cure rate achieved by the sequential regimen depends on the drug combination rather than on the length of the therapy (32).

We also found, for the first time, that the sequential regimen achieved similar eradication rates in patients with either high or low bacterial density. This was definitely different from what was observed with seven-day triple therapy. Such a finding adds further information to recent observations that the efficacy of the sequential regimen does not seem to be affected by factors that have been shown to drastically influence triple therapy success, such as presence of $\mathrm{CagA}$-negative strains, antibiotic bacterial resistance, smoking habits and nonulcer dyspepsia (42). Of note, it was previously found that a 10-day levofloxacin-amoxycillin-based triple therapy achieved an acceptable eradication rate in patients who failed two or more therapeutic attempts (38). Recently, by using such a therapy regimen as retreatment, we were able to cure $H$ pylori infection in $92 \%$ of patients harbouring both clarithromycin- and metronidazole-resistant strains (49). Therefore, such an approach could be also considered in the event of sequential regimen failure.

As far as compliance and side effects are concerned, we found that compliance was equally good for all three therapeutic regimens, given that therapy was stopped in only $2.8 \%$ of the enrolled patients. Moreover, in agreement with results from other studies $(14,33)$, the overall incidence of side effects was acceptably low for each therapy regimen, without a significant difference among the three schedules, and all side effects were self-limiting after the therapy ended.

\section{CONCLUSIONS}

Standard seven-day triple therapy is continuing to give disappointing eradication rates, especially in patients harbouring a high bacterial load. Ten-day triple therapy failed to significantly increase the $H$ pylori eradication rate achieved by the standard seven-day regimen. This clearly shows that triple therapy failure is due to an intrinsic weakness of such schedules rather than to duration of therapy. On the contrary, the 10-day sequential regimen was significantly more effective than both triple regimens, irrespective of bacterial density in the stomach. Therefore, the use of such an effective sequential regimen could be considered as first-line therapy in primary clinical practice.

8. Sharma VK, Howden CW. A national survey of primary care physicians' perceptions and practices related to Helicobacter pylori infection. J Clin Gastroenterol 2004;38:326-31.

9. Della Monica P, Lavagna A, Masoero G, Lombardo L, Crocella L, Pera A. Effectiveness of Helicobacter pylori eradication treatments in a primary care setting in Italy. Aliment Pharmacol Ther 2002;16:1269-75

10. Shirin H, Birkenfeld S, Shevah O, et al. Application of Maastricht 2-2000 guidelines for the management of Helicobacter pylori among specialists and primary care physicians in Israel: Are we missing the malignant potential of Helicobacter pylori? J Clin Gastroenterol 2004:38:322-5

11. Laheij RJ, Rossum LG, Jansen JB, Straatman H, Verbeek AL. Evaluation of treatment regimens to cure Helicobacter pylori infection - a meta-analysis. Aliment Pharmacol Ther 1999;13:857-64.

12. Janssen MJ, Van Oijen AH, Verbeek AL, Jansen JB, De Boer WA A systematic comparison of triple therapies for treatment of Helicobacter pylori infection with proton pump inhibitor/ranitidine bismuth citrate plus clarithromycin and either amoxycillin or a nitroimidazole. Aliment Pharmacol Ther 2001;15:613-24.

13. Calvet X, Garcia N, Lopez T, Gisbert JP, Gene E, Roque M. A meta- 
analysis of short versus long therapy with a proton pump inhibitor, clarithromycin and either metronidazole or amoxycillin for treating Helicobacter pylori infection. Aliment Pharmacol Ther 2000;14:603-9.

14. Zullo A, Rinaldi V, Winn S, et al. A new highly effective short-term therapy schedule for Helicobacter pylori eradication. Aliment Pharmacol Ther 2000;14:715-8.

15. Zullo A, Vaira D, Vakil N, et al. High eradication rates of Helicobacter pylori with a new sequential treatment. Aliment Pharmacol Ther 2003;17:719-26. (Erratum 2003;17:1205).

16. Perri F, Clemente R, Festa V, et al. Relationship between the results of pre-treatment urea breath test and efficacy of eradication of Helicobacter pylori infection. Ital J Gastroenterol Hepatol 1998;30:146-50.

17. Moshkowitz M, Konikoff FM, Peled Y, et al. High Helicobacter pylori numbers are associated with low eradication rate after triple therapy. Gut 1995;36:845-7.

18. Talamini G, Zamboni G, Cavallini G. Antral mucosal Helicobacter pylori infection density as a risk factor of duodenal ulcer. Digestion 1997;58:211-7.

19. Zullo A, Rinaldi V, Hassan C, et al. Helicobacter pylori and plasma ammonia levels in cirrhotics: Role of urease inhibition by acetohydroxamic acid. Ital J Gastroenterol Hepatol 1998;30:405-9.

20. Hunt R, Fallone C, Veldhuyzen van Zanten S, et al. Canadian Helicobacter Study Group Consensus Conference: Update on the management of Helicobacter pylori - an evidence-based evaluation of six topics relevant to clinical outcomes in patients evaluated for H pylori infection. Can J Gastroenterol 2004;18:547-54.

21. Rinaldi V, Zullo A, De Francesco V, et al. Helicobacter pylori eradication with proton pump inhibitor-based triple therapies and re-treatment with ranitidine bismuth citrate-based triple therapy. Aliment Pharmacol Ther 1999;13:163-8.

22. Bigard MA, Delchier JC, Riachi G, Thibault P, Barthelemy P. One-week triple therapy using omeprazole, amoxycillin and clarithromycin for the eradication of Helicobacter pylori in patients with non-ulcer dyspepsia: Influence of dosage of omeprazole and clarithromycin. Aliment Pharmacol Ther 1998;12:383-8.

23. Lee JM, Breslin NP, Hyde DK, Buckley MJ, O'Morain CA. Treatment options for Helicobacter pylori infection when proton pump inhibitor-based triple therapy fails in clinical practice. Aliment Pharmacol Ther 1999;13:489-96.

24. Hawkey CJ, Atherton JC, Treichel HC, Thjodleifsson B, Ravic M. Safety and efficacy of 7-day rabeprazole- and omeprazole-based triple therapy regimens for eradication of Helicobacter pylori in patients with documented peptic disease. Aliment Pharmacol Ther 2003;17:1065-74

25. Kashimura H, Suzuki K, Hassan M, et al. Polaprezinc, a mucosal protective agent, in combination with lansoprazole, amoxycillin and clarithromycin increases the cure rate of Helicobacter pylori infection. Aliment Pharmacol Ther 1999;13:483-7.

26. Wong BC, Chang FY, Abid S, et al. Triple therapy with clarithromycin, omeprazole, and amoxicillin for eradication of Helicobacter pylori in duodenal ulcer patients in Asia and Africa. Aliment Pharmacol Ther 2000;14:1529-35.

27. Laine L, Fennerty MB, Osato M, et al. Esomeprazole-based Helicobacter pylori eradication therapy and the effect of antibiotic resistance: Results of three US multicenter, double-blind trials. Am J Gastroenterol 2000;95:3393-8.

28. Vakil N, Cutler A. Ten-day triple therapy with ranitidine bismuth citrate, amoxicillin, and clarithromycin in eradicating Helicobacter pylori. Am J Gastroenterol 1999;94:1197-9.

29. Veldhuyzen van Zanten S, Machado S, Lee J. One-week triple therapy with esomeprazole, clarithromycin and metronidazole provides effective eradication of Helicobacter pylori infection. Aliment Pharmacol Ther 2003;17:1381-7.

30. Altintas E, Sezgin O, Ulu O, Aydin O, Camdeviren H. Maastricht Il treatment scheme and efficacy of different proton pump inhibitors in eradicating Helicobacter pylori. World J Gastroenterol 2004;10:1656-8.

31. Huang J-Q, Hunt RH. Treatment after failure: The problem of "nonresponders". Gut 1999;45(Suppl 1):140-4.

32. De Francesco V, Zullo A, Hassan C, et al. The prolongation of triple therapy for Helicobacter pylori does not allow reaching therapeutic outcome of sequential scheme: A prospective, randomised study. Dig Liver Dis 2004;36:322-6.

33. Gene E, Calvet X, Azagra R, Gisbert JP. Triple vs quadruple therapy for treating Helicobacter pylori infection: A meta-analysis. Aliment Pharmacol Ther 2003;17:1137-43.

34. Graham DY, Belson G, Abudayyeh S, Osato MS, Dore MP, El-Zimaity HM. Twice daily (mid-day and evening) quadruple therapy for $\mathrm{H}$ pylori infection in the United States. Dig Liver Dis 2004;36:384-7.

35. Zullo A, Hassan C, Morini S. Quadruple therapy as a first-line Helicobacter pylori treatment: Past or future? Dig Liver Dis 2004:36:377-9.

36. Cammarota G, Cianci R, Cannizzaro O, et al. Efficacy of two oneweek rabeprazole/levofloxacin-based triple therapies for Helicobacter pylori infection. Aliment Pharmacol Ther 2000;14:1339-43.

37. Zullo A, Hassan C, De Francesco V, et al. A third-line levofloxacinbased rescue therapy for Helicobacter pylori eradication. Dig Liver Dis 2003;35:232-6.

38. Watanabe Y, Aoyama N, Shirasaka D, et al. Levofloxacin based triple therapy as a second-line treatment after failure of Helicobacter pylori eradication with standard triple therapy. Dig Liver Dis 2003;35:711-5.

39. Di Mario F, Aragona G, Dal Bo N, et al. Use of bovine lactoferrin for Helicobacter pylori eradication. Dig Liver Dis 2003;35:706-10.

40. Zullo A, De Francesco V, Scaccianoce G, et al. Quadruple therapy with lactoferrin for Helicobacter pylori eradication: A randomised, multicentre study. Dig Liver Dis 2005;37:496-500.

41. De Francesco V, Zullo A, Hassan C, et al. Two new treatment regimens for Helicobacter pylori eradication: A randomised study. Dig Liver Dis 2001;33:676-9.

42. De Francesco V, Zullo A, Margiotta M, et al. Sequential treatment for Helicobacter pylori infection does not share the risk factors of triple therapy failure. Aliment Pharmacol Ther 2004;19:407-14.

43. Hassan C, De Francesco V, Zullo A, et al. Sequential treatment for Helicobacter pylori eradication in duodenal ulcer patients: Improving the cost of pharmacotherapy. Aliment Pharmacol Ther 2003;18:641-6.

44. Focareta R, Forte G, Forte F, et al. Could the 10-days sequential therapy be considered a first choice treatment for the eradication of Helicobacter pylori infection? Dig Liver Dis 2003;35(Suppl 4):S33. (Abst)

45. Zullo A, Hassan C, Morini S, et al. Sequential therapy for $H$ pylori: An "aberrant" therapy ready for general use. Dig Liver Dis 2004;36:852-3.

46. McLoughlin R, Racz I, Buckley M, O'Connor M, O'Morain C. Therapy of Helicobacter pylori. Helicobacter 2004;9(Suppl 1):42-8.

47. Murakami K, Fujioka T, Okimoto T, Sato R, Kodama M, Nasu M. Drug combinations with amoxycillin reduce selection of clarithromycin resistance during Helicobacter pylori eradication therapy. Int J Antimicrob Agents 2002;19:67-70.

48. de Boer WA, Kuipers EJ, Kusters JG. Sequential therapy; a new treatment for Helicobacter pylori infection. But is it ready for general use? Dig Liver Dis 2004;36:311-4.

49. Gatta L, Zullo A, Perna F, et al. A 10-day levofloxacin-based triple therapy in patients who have failed two eradication courses. Aliment Pharmacol Ther 2005;22:45-9. 


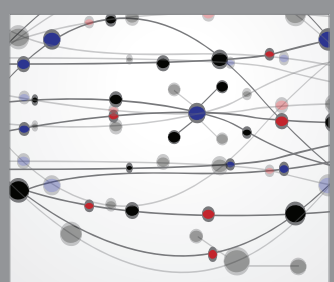

The Scientific World Journal
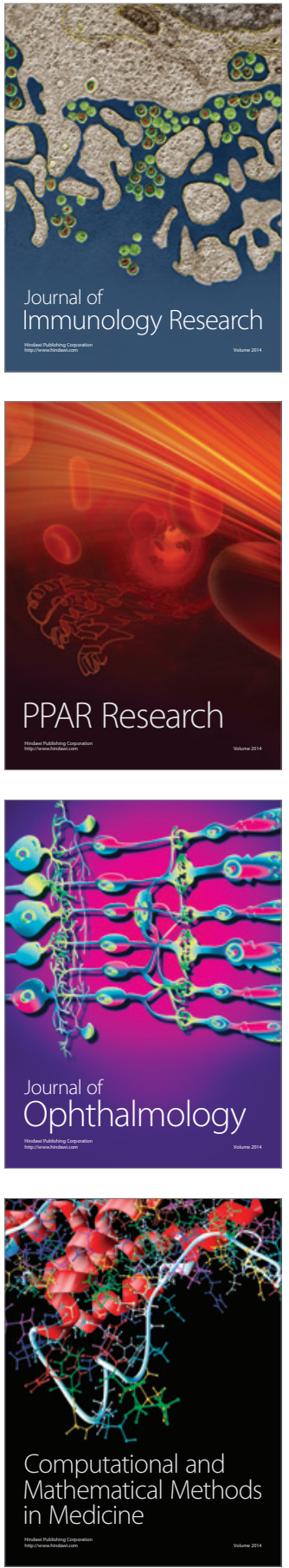

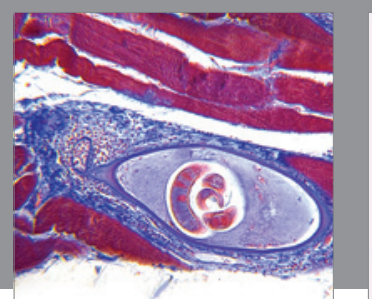

Gastroenterology Research and Practice

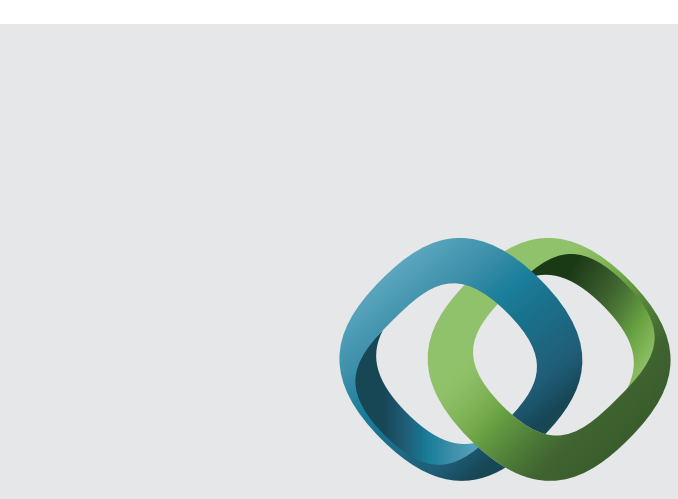

\section{Hindawi}

Submit your manuscripts at

http://www.hindawi.com
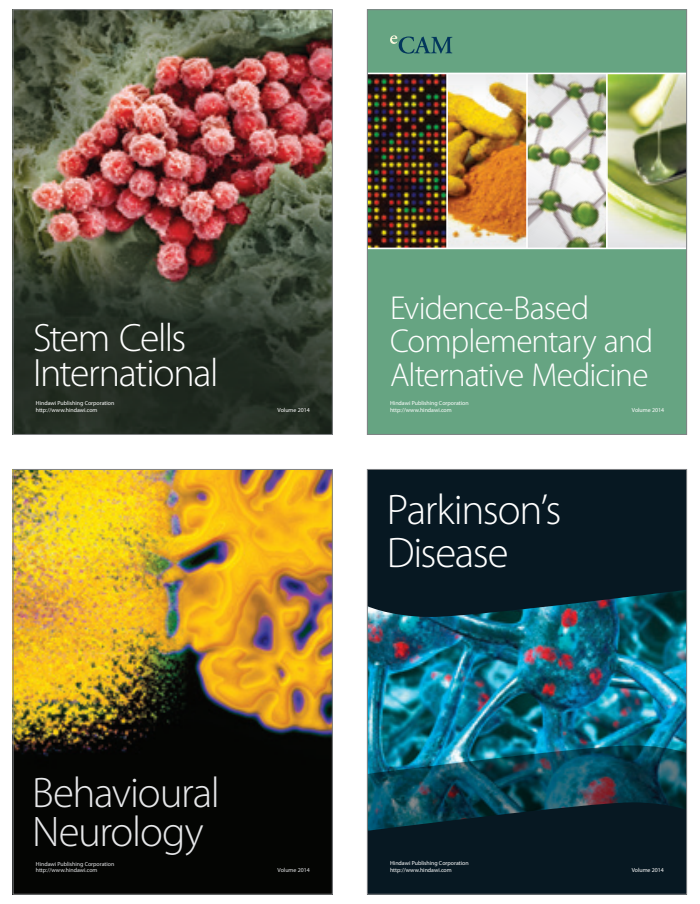
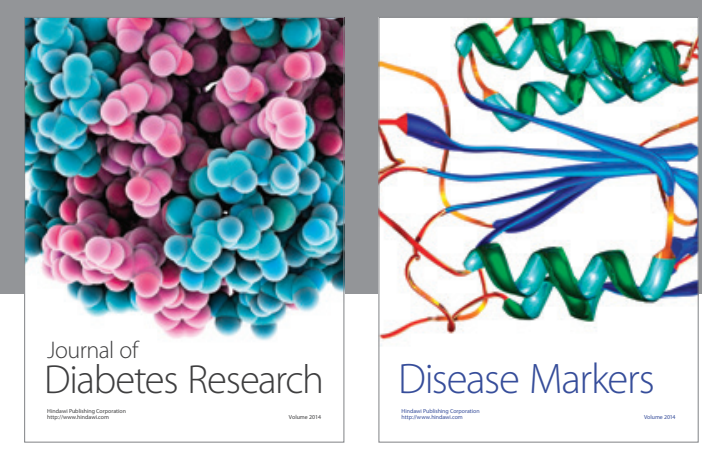

Disease Markers
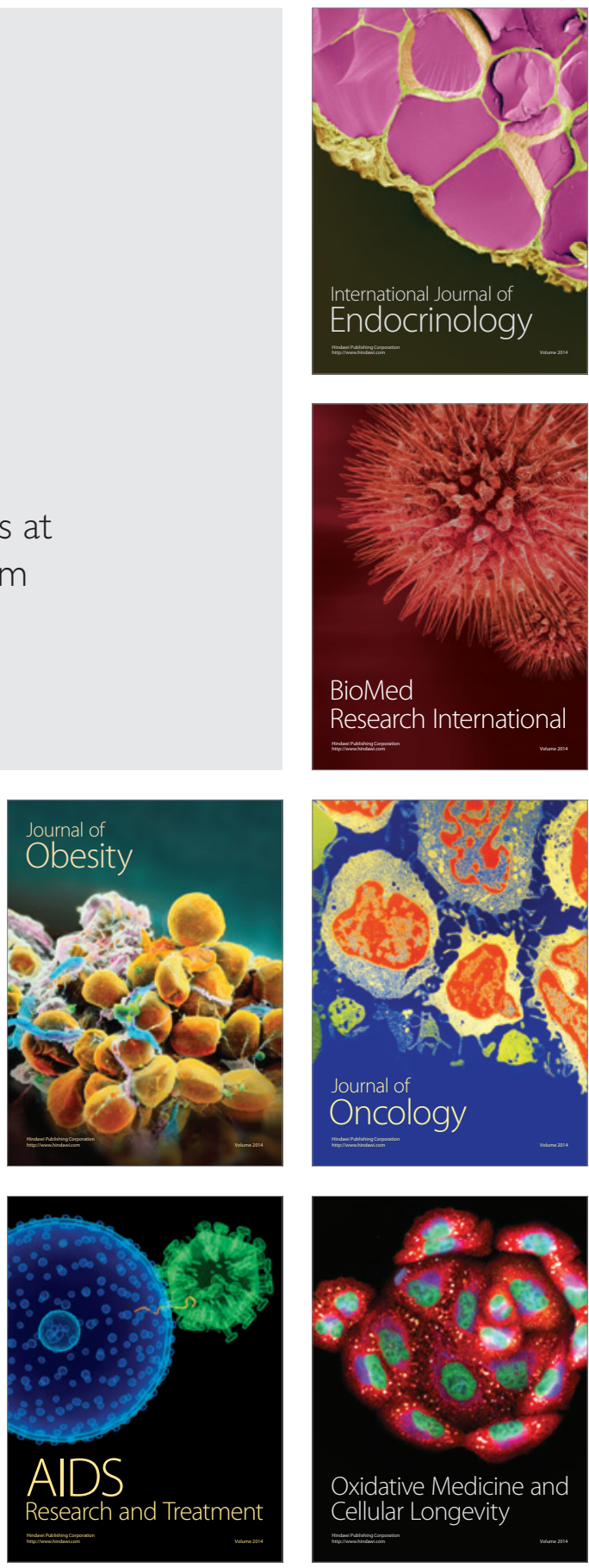